\title{
Sebastian Skuza
}

Uniwersytet Warszawski

\section{Anna Modzelewska}

Uniwersytet Jagielloński

Marta Szeluga-Romańska

Politechnika Gdańska

\section{PROFESJONALIZACJA ZAWODU DZIENNIKARZA W OBLICZU KONWERGENCJI MEDIÓW}

Abstract

\section{PROFESSIONALIZATION OF THE JOURNALIST PROFESSION IN THE CONTEXT OF MEDIA CONVERGENCE}

The aim of this article is to broaden the current knowledge about changes in the profession of a journalist caused by the digitization and convergence of the media. The authors carried out surveys among journalists, exploring issues related to their opinion on professionalization, the process of changes in the media as well as opportunities and threats indicated by new media.

Key words: professionalism, professional journalism, fake news, journalism

\section{Wstęp}

Transformacja ustrojowa po 1989 roku spowodowała konieczność wypracowania standardów dziennikarskich odpowiadających powszechnie uznawanym w krajach demokratycznych, będąc jednocześnie szansą doskonalenia zawodowego oraz bezstronnego relacjonowania ${ }^{1}$. Obecnie w wyniku upowszechnienia Internetu oraz 1991, s. 8.

1 J. Olędzki, Wstęp, [w:] J. Olędzki (red.), Polskie media w okresie przemian, OBP, Warszawa 
zjawisk takich jak cyfryzacja i konwergencja mediów jesteśmy świadkami kolejnej rewolucji na rynku medialnym. Spowodowało to zmiany w dziennikarstwie uważanym niegdyś za rodzaj służby społecznej, a obecnie coraz częściej po prostu za zawód medialny ${ }^{2}$. Wykorzystanie nowych mediów, w tym ich potencjału aktywności oddolnej, może stanowić dla mediów zarówno szansę, jak i zagroże$n^{3} e^{3}$. Konwergencja umożliwia przepływ informacji pomiędzy platformami medialnymi, współpracę różnych przemysłów medialnych, migracyjne zachowanie odbiorców, którzy samodzielnie wyszukują i zestawiają informacje 4 . Wymusza to konieczność bycia tzw. superdziennikarzem, posiadającym umiejętności zbierania informacji, jak również atrakcyjnej formy ich prezentacji ${ }^{5}$. Dziennikarze powinni zatem stać się wielozadaniowymi profesjonalistami zarówno w sferze medialnej (tworzenia treści do wielu rodzajów mediów), tematycznej (brak specjalizacji tematycznej), jak i produkcyjnej (jedna osoba tworzy materiał na różnych etapach produkcji $)^{6}$.

$\mathrm{W}$ obliczu zachodzących zmian istotne wydaje się podjęcie badań na temat współczesnego profesjonalizmu dziennikarskiego. Celem niniejszego artykułu jest poszerzenie dotychczasowej wiedzy na temat zmian zawodu dziennikarza spowodowanych cyfryzacją i konwergencją mediów. Autorzy zrealizowali badania ankietowe wśród dziennikarzy, eksplorując zagadnienia dotyczące ich opinii na temat profesjonalizacji, procesu zmian w mediach oraz szans i zagrożeń wynikających z nowych mediów.

Profesjonalizm stanowił jedno $\mathrm{z}$ najważniejszych wyzwań dla dziennikarzy po transformacji ustrojowej ${ }^{7}$. Można powiedzieć, że środowisko dziennikarskie zostało poddane takiej transformacji w przyspieszonej formie, zwłaszcza w zakresie funkcjonowania w nowych warunkach oraz konieczności wypracowania standardów profesjonalizmu zawodowego i etyki, które w innych systemach medialnych kształtowały się przez lata. Problematyka zawodowstwa dziennikarskiego była więc popularnym tematem badań podejmowanych w latach 90 . XX wieku - w związku z potrzebą tworzenia nowych standardów tego zawodu wynikających

2 B. Nierenberg, Media Management: A Comparative Analysis of European and American Systems, Jagiellonian University Press, Kraków 2016, s. 13.

${ }^{3}$ I. Hofman, Polityka, media, społeczeństwo. Studia i szkice, Wydawnictwo Adam Marszałek, Toruń 2007, s. 6.

${ }^{4} \mathrm{H}$. Jenkins, Kultura konwergencji. Zderzenie starych i nowych mediów, tłum. M. Bernatowicz, M. Filiciak, Wydawnictwa Akademickie i Profesjonalne, Warszawa 2007, s. 9.

${ }^{5}$ P. Wieczorek, Dziennikarz profesjonalny czy obywatelski? Przyszłość zawodu w wirtualnym newsroomie, [w:] A. Jaskiernia, K. Gajlewicz-Korab (red.), Rozwój internetu a zmiany w mediach, systemach medialnych oraz społecznych, Wydawnictwo Uniwersytetu Warszawskiego, Warszawa 2016, s. 280.

${ }^{6}$ K. Siezieniewska, Zawód dziennikarza w obliczu konwergencji mediów, Uniwersytet Warszawski, Warszawa 2014, s. 366.

${ }^{7}$ L. Szot, Wplyw profesjonalizmu dziennikarzy na transformacje polskiej prasy po 1989 roku, „Studia Medioznawcze” 2010, nr 2 (41), s. 27-38. 
$\mathrm{z}$ dostosowywania do zmian uwarunkowań otoczenia zewnętrznego ${ }^{8}$. W literaturze przedmiotu problematyka profesjonalizmu dziennikarskiego pojawia się najczęściej w opracowaniach dotyczących standardów zawodowych i etycznych ${ }^{9}$, warsztatu pracy $^{10}$, analizy konkretnych studiów przypadków ${ }^{11}$ oraz jako temat przewodni $\mathrm{w}$ monografiach pokonferencyjnych ${ }^{12}$.

\section{Profesjonalizm dziennikarski - próba definicji}

Pojęcie „profesja” wywodzi się z języka łacińskiego (professio) i oznacza „działania jednostki nakierowane na otoczenie, czy to w postaci aktów mowy, czy też czynności stanowiących źródło utrzymania" ${ }^{13}$. Słownik języka polskiego ${ }^{14}$ definiuje to pojęcie na trzy sposoby:

1. czyjeś duże umiejętności i wysoki poziom wykonywanej pracy;

2. zawodowe uprawianie jakiejś specjalności;

3. wyraz lub związek wyrazowy charakterystyczny dla języka określonego środowiska zawodowego.

${ }^{8}$ J. Olędzki, Profesjonalizm w zawodzie dziennikarskim. Teoria i praktyka, [w:] Polskie przemiany lat 90-tych. Materialy z konferencji naukowej zorganizowanej przez WDiNP UW w dniach 1-2.12.1994r., Wydawnictwo Uniwersytetu Warszawskiego, Warszawa 1996, s. 267-290; J.L. Curry, Poland's Journalists: Professionalism and Politics, Cambridge University Press, Cambridge 1990; J. Olędzki, Polish Journalists: Professionals or Not?, [w:] D.H. Weaver, W. Wu, The Global Journalist: News People around the World, Hampton Press, New York 1998, s. 277-297.

9 T. Kononiuk, Zawodowstwo w dziennikarstwie - wyzwania XXI wieku, „Studia Medioznawcze” 2001, nr 3 (4), s. 15-23; M. Głowacki, Dziennikarze polscy w świetle studiów porównawczych systemów odpowiedzialności mediów w Europie, „Studia Medioznawcze” 2013, nr 1, s. 29-43; K. Pokorna-Ignatowicz, Problemy zawodowe dziennikarzy w Polsce u progu nowego wieku na podstawie analizy branżowego miesięcznika „Press”, „Studia Medioznawcze” 2001, nr 3 (4), s. 23-34; B. Dobek-Ostrowska, P. Barczyszyn, S. Michel, Zmiana w dziennikarstwie. Kultura zawodowa polskich dziennikarzy (badania ilościowe), „Studia Medioznawcze” 2013, nr 1, s. 11-26; M. Drożdż, Etyczność jako wyznacznik profesjonalizmu, [w:] K. Wolny-Zmorzyński, K. Konarski (red.), Klinika dziennikarska - credo, Wydawnictwo Uniwersytetu Wrocławskiego, Wrocław 2016, s. 25-42.

${ }_{10}$ M. Chyliński, Metodologia researchu a profesjonalizm dziennikarski, „Studia Medioznawcze” 2012, nr 3 (50), s. 43-61.

${ }^{11}$ L. Szot, Dziennikarze mediów lokalnych. Pomiędzy profesjonalizmem a koniecznościa przetrwania, Wydawnictwo Uniwersytetu Wrocławskiego, Wrocław 2013; T. Kononiuk, Profesjonalizm w prasie lokalnej, „Forum Dziennikarzy” 1999, nr 3, s. 10-11; M. Lewandowska, Profesjonalizm dziennikarski Kuby Wojewódzkiego, Wydawnictwo Naukowe Uniwersytetu Mikołaja Kopernika, Toruń 2019.

12 J. Adamowski, A. Jupowicz-Ginalska, Zmierzch profesjonalnego dziennikarstwa? Konferencja naukowa Wydziału Dziennikarstwa i Nauk Politycznych Uniwersytetu Warszawskiego i Krajowej Rady Radiofonii i Telewizji, Warszawa, 8 marca 2012, Oficyna Wydawnicza ASPRA-JR, Warszawa 2012; Polskie przemiany lat 90-tych. Materiały z konferencji naukowej..., dz. cyt.

${ }_{13}$ P. Pilch, Ewolucja denotacji i konotacji pojęcia „profesji”, „Problemy Profesjologii” 2011, nr 2, s. 175.

${ }_{14}$ Słownik języka polskiego, https://sjp.pwn.pl/sjp/profesjonalizm;2572537.html (dostęp: 20.07.2019). 
Piotr Pilch zauważa, że procesy profesjonalizacji mogą przebiegać dwutorowo: po pierwsze, jako wykształcanie się nowych specjalizacji w ramach dotychczas istniejących zawodów lub pojawianie się nowych zawodów w rezultacie wzrostu zapotrzebowania na ich nowe rodzaje; po drugie, gdy dotychczasowe pasje stają się zawodem (przejście od „pracy” amatorskiej do zawodowej) ${ }^{15}$. Polska literatura socjologiczna ${ }^{16}$ oraz Słownik socjologiczny ${ }^{17}$ koncentrują się głównie na rozumieniu pierwszym, czyli procesie wykształcania się i definiowania nowych zawodów, co wiąże się $\mathrm{z}$ określonym zakresem wymaganej wiedzy oraz kompetencji w danym zawodzie. Daniel Hallin i Paolo Mancini wskazali trudność definicyjną terminu „profesjonalizm dziennikarski”, wynikającą z faktu, iż w „przypadku dziennikarstwa nie istnieje żadna systematyczna wiedza czy podobna doktryna”, tak jak w przypadku medycyny czy prawa ${ }^{18}$. Wyżej wymienieni badacze zaproponowali następujące wyznaczniki profesjonalizacji ${ }^{19}$ :

1. autonomia - niezależność od zewnętrznych podmiotów, zespołowa kontrola pracy;

2. odrębne normy zawodowe - istnienie wspólnych norm, wartości i stylu życia;

3. służba interesowi publicznemu - przestrzeganie zasad etyki służby publicznej.

Akty powszechnie obowiązującego w Polsce prawa nie definiują pojęcia profesjonalizmu dziennikarskiego. W ustawie z dnia 26 stycznia 1984 r. - Prawo prasowe określono wyłącznie, co jest obowiązkiem dziennikarza, tj. służba społeczeństwu i państwu oraz konieczność działania zgodnego z etyką zawodową i zasadami współżycia społecznego, w granicach określonych przepisami prawa ${ }^{20}$. W kontekście profesjonalizmu dziennikarskiego istotne wydają się zapisy art. 12 ust. 1 ustawy Prawo prasowe, stanowiące, iż dziennikarz jest zobowiązany ${ }^{21}$ :

1. zachować szczególną staranność i rzetelność przy zbieraniu i wykorzystaniu materiałów prasowych, zwłaszcza sprawdzić zgodność z prawdą uzyskanych wiadomości lub podać ich źródło;

2. chronić dobra osobiste, a ponadto interesy działających w dobrej wierze informatorów i innych osób, które okazują mu zaufanie;

3. dbać o poprawność języka i unikać używania wulgaryzmów.

15 P. Pilch, Ewolucja denotacji..., dz. cyt., s. 184.

${ }_{16}$ Zob. B. Gałęski, Zawód jako kategoria socjologiczna. Formowanie się zawodu rolnika, „Studia Socjologiczne” 1963, nr 3 (10), s. 46-72; O. Łodyga, Zawód jako kategoria badań socjologicznych, „Prace Naukowe. Pedagogika” 1999-2001, nr 8-10, s. 165-171.

${ }^{17}$ K. Olechnicki, P. Załęcki, Słownik socjologiczny, Graffiti, Toruń 1998, s. 164.

18 D. Hallin, P. Mancini, Systemy medialne. Trzy modele mediów i polityki w ujęciu porównawczym, Wydawnictwo Uniwersytetu Jagiellońskiego, Kraków 2007, s. 34.

19 Tamże, s. 34-37.

${ }^{20}$ Ustawa z dnia 26 stycznia 1984 r. - Prawo prasowe, Dz.U. z 2018 r., poz. 1914, art. 10 ust. 1.

${ }^{21}$ Tamże, art. 12 ust. 1. 
Ustawa z dnia 29 grudnia 1992 r. o radiofonii i telewizji, zwana „ustawą medialną, również nie definiuje terminu profesjonalizm, choć pojęcie to pojawia się w kontekście kryteriów powoływania członków zarządów mediów publicznych ${ }^{22}$ :

Członkowie zarządów i osoby zajmujące kierownicze stanowiska w jednostkach publicznej radiofonii i telewizji kierują się w swojej pracy oraz w ocenie dziennikarzy i innych twórców im podległych zasadami p r of e s j o n a li z m u, uczciwości i rzetelności oraz wskazaniami zawartymi w art. 21 ust. 1a i 2 ustawy.

Mając na względzie powyższe, zdaniem Lucyny Szot, w aktualnym stanie prawnym, „poza weryfikacją sądową, brakuje czytelnych i jednolitych kryteriów weryfikacji poziomu profesjonalizmu zawodowego dziennikarzy”. Ponadto autorka ta zauważa, że wobec braku organu takiego jak rada prasowa weryfikacja profesjonalizmu dziennikarskiego jest możliwa wyłącznie na podstawie wyniku postępowania sądowego ( $w$ indywidualnych przypadkach) o naruszenie dóbr osobistych przez media $\mathrm{z}$ udziałem dziennikarzy ${ }^{23}$.

Przejawem profesjonalizmu dziennikarskiego na poziomie jednostkowym może być stworzenie produktu dziennikarskiego cechującego się obiektywizmem przejawiającym się w bezstronności i faktograficzności ${ }^{24}$. Wyrazem rozwoju ogólnego procesu profesjonalizacji jest natomiast przyjęcie i kontrolowanie przez środowisko zbioru zasad działalności zawodowej, zawartego w dziennikarskim kodeksie etycznym ${ }^{25}$. Analiza kodeksów deontologicznych organizacji i stowarzyszeń dziennikarskich $\mathrm{w}$ Polsce wykazała brak zdefiniowania pojęcia profesjonalizmu dziennikarskiego ${ }^{26}$.

\section{Profesjonalizm dziennikarski w obliczu konwergencji mediów - wnioski z badań}

W celu poszerzenia dotychczasowej wiedzy z zakresu profesjonalizmu dziennikarskiego autorzy przygotowali kwestionariusz ankiety składający się z dwunastu pytań o charakterze zamkniętym i otwartym. Kwestionariusz ankiety w lipcu 2019 roku został przekazany dziennikarzom reprezentującym różnorodne środowiska medialne. W badaniu wzięło udział 23 dziennikarzy oraz jedna osoba pracująca w branży okołomedialnej, współpracująca z dziennikarzami (zob. Tabela 1). Średni staż pracy osób w badanej grupie wynosi ponad 12 lat.

${ }^{22}$ Ustawa z dnia 29 grudnia 1992 r. o radiofonii i telewizji, Dz.U. z 2019 r., poz. 361 z późn. zm., art. 27 ust. 11 pkt 7.

${ }^{23}$ L. Szot, Wplyw profesjonalizmu..., dz. cyt., s. 29.

${ }^{24}$ Tamże, s. 28.

25 Tamże, s. 29.

${ }^{26}$ Zob. Kodeks Etyki Stowarzyszenia Dziennikarzy Polskich, https://sdp.pl/kodeks-etykisdp/; Karta Etyczna Mediów, http://www.dziennikarzerp.pl/wp-content/uploads/2010/06/karta dziennikarzy.pdf; Dziennikarski Kodeks Obyczajowy, http://www.dziennikarzerp.pl/wp-content/ uploads/2010/06/kodeks.pdf (dostęp: 20.07.2019). 
Tabela 1. Opis badanej próby

\begin{tabular}{|c|c|c|c|}
\hline Lp. & $\begin{array}{c}\text { Numer } \\
\text { respondenta }\end{array}$ & Rodzaj mediów & Staż pracy (lata) \\
\hline Dziennikarz 1 & 14119700 & Radio & 22 \\
\hline Dziennikarz 2 & 14113927 & Telewizja & 19 \\
\hline Dziennikarz 3 & 14113700 & Prasa & 4 \\
\hline Dziennikarz 4 & 14112790 & Prasa & 7 \\
\hline Dziennikarz 5 & 14109085 & Radio & 27 \\
\hline Dziennikarz 6 & 14108030 & Prasa & 20 \\
\hline Dziennikarz 7 & 14106972 & Prasa & 23 \\
\hline Dziennikarz 8 & 14106778 & Prasa & 20 \\
\hline Dziennikarz 9 & 14104963 & Radio & 11 \\
\hline Dziennikarz 10 & 14104225 & Media elektroniczne & 3 \\
\hline Dziennikarz 11 & 14103898 & Media elektroniczne & 7 \\
\hline Dziennikarz 12 & 14103703 & Prasa, media elektroniczne & 18 \\
\hline Dziennikarz 13 & 14103060 & Telewizja & 15 \\
\hline Dziennikarz 14 & 14102966 & Telewizja & 11 \\
\hline Dziennikarz 15 & 14102773 & Media elektroniczne & 3 \\
\hline Dziennikarz 16 & 14102523 & Prasa, media elektroniczne & 5 \\
\hline Dziennikarz 17 & 14102459 & Prasa & 25 \\
\hline Współpracownik & 14102379 & Inne: współpracuje z mediami & 4 \\
\hline Dziennikarz 18 & 14100474 & Prasa & 25 \\
\hline Dziennikarz 19 & 14098177 & Media elektroniczne & 12 \\
\hline Dziennikarz 20 & 14096171 & Prasa & 7 \\
\hline Dziennikarz 21 & 14083671 & Media elektroniczne & 8 \\
\hline Dziennikarz 22 & 14083524 & Media elektroniczne & 7 \\
\hline Dziennikarz 23 & 14080573 & Prasa, media elektroniczne & 5 \\
\hline
\end{tabular}

Źródło: opracowanie na podstawie badań własnych.

Pytania 1 i 2 miały charakter wprowadzający, ich celem była identyfikacja próby oraz pozyskanie podstawowych informacji na temat badanych. Odpowiedzi na te pytania zostały ujęte w Tabeli 1 oraz na Wykresach 1 i 2.

Dziennikarze mogli wskazać więcej niż jeden rodzaj mediów, w którym pracują. Trzech respondentów (Dziennikarz 12, Dziennikarz 16 i Dziennikarz 23) wskazało, że aktualnie pracują w prasie oraz mediach elektronicznych.

Odpowiedź na pytanie 2: Ile lat pracuje Pani/Pan $w$ mediach? zawarta jest w Tabeli 1 . 
Wykres 1. Odpowiedzi na pytanie: Proszę podać rodzaj mediów, w którym Pani/Pan aktualnie pracuje

\begin{tabular}{|c|c|c|c|}
\hline wiele odpowiedzi & $50 \%$ & $100 \%$ procentowo | & głosów \\
\hline prasa & & $46 \%$ & 11 \\
\hline radio & $\square$ & $13 \%$ & 3 \\
\hline telewizja & - & $13 \%$ & 3 \\
\hline media elektroniczne & 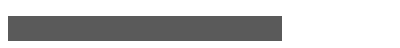 & $38 \%$ & 9 \\
\hline inne, jakie? & $\square$ & $4 \%$ & 1 \\
\hline
\end{tabular}

odpowiedzi otwarte

Nie pracuję w zawodzie, ale mam kontakt z mediami

Respondent 14102379

Źródło: opracowanie na podstawie badań własnych.

Pytanie 3 miało charakter sondujący: Czy wobec zmian wynikajacych z cyfryzacji i konwergencji Pani/Pana zdaniem definicja dziennikarza ujęta $w$ ustawie Prawo prasowe $z$ dnia 26 stycznia 1984 r. wymaga zredefiniowania? Zgodnie $\mathrm{z}$ art. 7 ust. 2 pkt 5 wyżej wymienionej ustawy dziennikarzem jest osoba zajmująca się redagowaniem, tworzeniem lub przygotowywaniem materiałów prasowych, pozostająca $\mathrm{w}$ stosunku pracy z redakcją albo zajmująca się taką działalnością na rzecz i z upoważnienia redakcji. W przypadku twierdzącej odpowiedzi na pytanie respondenci byli proszeni o wskazanie zakresu proponowanych zmian. Odpowiedzi udzielone na powyższe pytanie przedstawia Wykres 2.

Wykres 2. Odpowiedzi na pytanie: Czy wobec zmian wynikajacych z cyfryzacji i konwergencji Pani/Pana zdaniem definicja dziennikarza ujęta w ustawie Prawo prasowe z dnia 26 stycznia 1984 r. wymaga zredefiniowania?



\footnotetext{
Tworzenie i redagowanie (uściślając - pisanie), przygotowywanie materiałów może być interpretowane jako przetwarzanie innych materiałów gotowych już napisanych wczesniej. Powielanie tych samych materiałów według mnie jest na granicy tworzenia nowych materiałów.

nie tylko stosunek pracy, nie tylko na zlecenie redakcji (bloger też może być dziennikarzem, jeśli tyl- $\quad$ Respondent 14109085 ko regularnie). To pomija też freelancerów. Definicja sprzed lat.

Za dziennikarza można uznać też osobę, która nie jest związana z żadną redakcją, ale pracuje na własny rachunek, publikując materiały w nowych mediach - FB, Youtube itd.

Zamieniłbym „prasowych” na „dziennikarskich”.

Respondent 14113927

Respondent 14104963

Respondent 14102966
}

Źródło: opracowanie na podstawie badań własnych. 
Większość badanych (14 ankietowanych, tj. 58,33\%) opowiedziała się za brakiem konieczności nowelizacji definicji pojęcia dziennikarza. W przypadku respondentów, którzy udzielili odpowiedzi twierdzącej (10 ankietowanych, tj. 41,67\%), tylko czterech zaproponowało autorski zakres zmian. W udzielonych odpowiedziach otwartych respondenci zwrócili uwagę na potrzebę objęcia definicją także freelancerów, którzy tworzą materiały dziennikarskie, nie będąc na stałe zatrudnionymi i nie współpracując z jedną wybraną redakcją. Ponadto zwrócono uwagę na nieuwzględnienie w ustawowej definicji dziennikarza blogerów, którzy tworzą własne platformy do przekazywania informacji oraz publikacji artykułów, niebędące redakcjami w rozumieniu ustawy.

W pytaniu 4: Czy dostęp do zawodu dziennikarza powinien być regulowany? odpowiedzi rozłożyły się równomiernie. Dwunastu badanych (tj. 50\%) uważa, że dostęp do zawodu nie powinien być w żaden sposób ograniczony regulacyjnie. Natomiast 12 respondentów (tj. 50\%) opowiedziało się za koniecznością ograniczenia dostępu, z tego sześciu (25\%) jest za prawnym uregulowaniem dostępu do zawodu dziennikarza, a tylu samo jest zdania, że powinny istnieć w tym zakresie wyłącznie regulacje środowiskowe.

Wykres 3. Odpowiedzi na pytanie: Czy dostęp do zawodu dziennikarza powinien być regulowany?

\begin{tabular}{|c|c|c|c|}
\hline jedna odpowiedź & 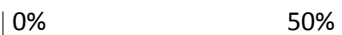 & $100 \%$ procentowo & głosów \\
\hline $\mathrm{Nie}$ & & $50 \%$ & 12 \\
\hline $\begin{array}{l}\text { Tak, powinny istnieć regulacje } \\
\text { prawne dopuszczające do wy- } \\
\text { konywania zawodu }\end{array}$ & & $25 \%$ & 6 \\
\hline $\begin{array}{l}\text { Tak, powinny istnieć regulacje } \\
\text { środowiskowe dopuszczające } \\
\text { do wykonywania zawodu }\end{array}$ & & $25 \%$ & 6 \\
\hline
\end{tabular}

Źródło: opracowanie na podstawie badań własnych.

W pytaniu 5 respondenci zostali poproszeni o udzielenie odpowiedzi na pytanie: Jak Pan/Pani rozumie termin „profesjonalizm dziennikarski”? Najczęściej powtarzającą się charakterystyką pojęcia był „obiektywizm”. Trafnie ilustruje to wypowiedź jednego $\mathrm{z}$ ankietowanych:

[Ważne jest] dawanie czytelnikowi pola do rozważań i refleksji - dziennikarz nie podaje czytelnikowi na tacy swojego stanowiska. Profesjonalny dziennikarz to taki, który wchodzi w interakcje z czytelnikiem, dając mu czas i narzędzia do wyrobienia własnej opinii [Dziennikarz 4].

W zbliżony sposób profesjonalizm definiował Dziennikarz 2:

Pełny i bezdyskusyjny obiektywizm poprzez ujawnianie prawdy i mówienie o niej w celu uświadomienia i poinformowania społeczeństwa o zachodzących sytuacjach, zmianach i rozwoju gatunku ludzkiego i innych gatunków, świata i nieograniczonych, popartych dowodami sytuacji w zgodzie z etyką i moralnością dziennikarza. 
Badani dziennikarze podkreślali też znaczenie znajomości warsztatu dziennikarskiego oraz rzetelności jako istotnych wyznaczników profesjonalizmu. Niektórzy respondenci wskazywali również etykę dziennikarską, przestrzeganie prawa oraz tajemnicy dziennikarskiej, a także niezależność i niezawisłość.

W pytaniu 6 ankietowani zostali zapytani: Który z wymienionych wyznaczników profesjonalizmu zawodu dziennikarza jest Pani/Pana zdaniem najważniejszy? W sugerowanych odpowiedziach posłużono się triadą profesjonalizmu opracowaną przez Jerzego Olędzkiego, aby sprawdzić, czy jest nadal aktualna ${ }^{27}$. Poza triadą była też możliwość samodzielnego zaproponowania najważniejszego wyznacznika. Odpowiedzi na powyższe pytanie zaprezentowano na Wykresie 4.

Wykres 4. Odpowiedzi na pytanie: Który z wymienionych wyznaczników profesjonalizmu zawodu dziennikarza jest Pani/Pana zdaniem najważniejszy?

\begin{tabular}{|c|c|c|c|c|}
\hline jedna odpowiedź & $50 \%$ & $100 \%$ & procentowo & głosów \\
\hline Warsztat & & & $33 \%$ & 8 \\
\hline Wiedza & & & $17 \%$ & 4 \\
\hline Etyka & & & $29 \%$ & 7 \\
\hline Inny, jaki? & 0 & & $21 \%$ & 5 \\
\hline \multicolumn{5}{|l|}{ odpowiedzi otwarte } \\
\hline \multicolumn{2}{|c|}{ zarówno warsztat, jak i etyka zawodu są istotne w jednakim stopniu } & & \multicolumn{2}{|c|}{ Respondent 14119700} \\
\hline \multicolumn{2}{|l|}{ Doświadczenie } & & \multicolumn{2}{|c|}{ Respondent 14103060} \\
\hline \multicolumn{2}{|l|}{ Rzetelność } & & \multicolumn{2}{|c|}{ Respondent 14098177} \\
\hline \multicolumn{2}{|c|}{ Umiejętność korzystania ze źródeł } & & \multicolumn{2}{|c|}{ Respondent 14083671} \\
\hline \multicolumn{2}{|l|}{ Rzetelność } & & \multicolumn{2}{|c|}{ Respondent 14080573} \\
\hline
\end{tabular}

Źródło: opracowanie na podstawie badań własnych.

Badani wskazali, że najważniejszymi wyznacznikami profesjonalizmu dziennikarskiego są: warsztat (8 ankietowanych - 33\%), etyka (7 ankietowanych - 29\%) oraz wiedza (4 ankietowanych $-17 \%$ ). Ponadto jeden $\mathrm{z}$ respondentów uznał, że takie wyznaczniki jak warsztat i etyka są ważne $\mathrm{w}$ równym stopniu. $\mathrm{W}$ pozostałych otwartych wypowiedziach pojawiła się rzetelność (3 respondentów - umiejętność korzystania ze źródeł także można zaliczyć do tej kategorii) oraz doświadczenie (1 respondent).

W pytaniu 7 badani zostali poproszeni o udzielenie odpowiedzi na pytanie: Jak ocenia Pan/Pani poziom wspótczesnego profesjonalizmu zawodu dziennikarza w Polsce? Większość ankietowanych oceniła poziom profesjonalizmu jako umiarkowany ( 15 ankietowanych - 62,5\%). Pozostali ankietowani uznali go za niski (6 ankietowanych - 25\%) lub bardzo niski (3 ankietowanych - 12,5\%). Na podkreślenie

${ }^{27}$ J. Olędzki, Profesjonalizm w zawodzie dziennikarskim..., dz. cyt., s. 281. 
zasługuje fakt, że żaden z respondentów nie udzielił odpowiedzi oceniającej profesjonalizm na poziomie wysokim lub bardzo wysokim.

Wykres 5. Jak ocenia Pan/Pani poziom wspótczesnego profesjonalizmu zawodu dziennikarza w Polsce?

\begin{tabular}{|c|c|c|c|c|c|}
\hline jedna odpowiedź & $0 \%$ & $50 \%$ & $100 \%$ & procentowo & głosów \\
\hline Bardzo wysoki & & & & $0 \%$ & 0 \\
\hline Wysoki & & & & $0 \%$ & 0 \\
\hline Umiarkowany & & & & $62,5 \%$ & 15 \\
\hline Niski & & & & $25 \%$ & 6 \\
\hline Bardzo niski & & & & $12 \%$ & 3 \\
\hline
\end{tabular}

Źródło: opracowanie na podstawie badań własnych.

W pytaniu 8 respondenci zostali poproszeni o udzielenie odpowiedzi na pytanie: Jakie działania sugerowałaby Pani/Pan, aby podnieść standardy profesjonalizmu dziennikarskiego? Odpowiedzi dziennikarzy można podzielić na trzy kategorie: stworzenie barier wejścia do zawodu i konieczność nieustannego rozwoju; podniesienie wymagań wobec jakości pracy dziennikarskiej; poprawienie warunków pracy. W przypadku pierwszej kategorii respondenci zauważali, że bardzo ważne jest zaostrzenie kryteriów selekcji w przyjmowaniu do pracy. Niektórzy wyrazili nawet pogląd o konieczności wprowadzenia egzaminu zawodowego. Badani dostrzegli także konieczność permanentnej nauki, rozwoju, podążania za zmieniającymi się technologicznie narzędziami pracy dziennikarza oraz nikłą użyteczność niektórych kursów zawodowych. Podkreślano też, że najskuteczniejszą nauką zawodu byłaby współpraca bardziej doświadczonych dziennikarzy z ich początkującymi kolegami. Badani zwrócili jednak uwagę, że taka forma współpracy budzi niepokój (związany z potencjalnym „zabraniem” miejsca pracy).

W drugiej kategorii odpowiedzi pojawiały się opinie, że obecnie w wielu publikowanych materiałach zauważalny jest brak obiektywizmu i etyki. Przyczyn takiego stanu rzeczy dopatrywano się między innymi w nadmiernych wpływach polityki oraz agencji reklamowych na zespoły dziennikarskie. Niektórzy respondenci uznali, że powinny istnieć kary za błędy merytoryczne oraz za rozpowszechnianie fake newsów. Dostrzeżono także potrzebę zmiany niektórych schematów pracy, na przykład przywiązywania większej wagi do jakości publikowanych materiałów, a nie szybkości.

Trzecia kategoria odpowiedzi to postulaty przede wszystkim podniesienia wynagrodzeń, tak aby motywowały do twórczego i etycznego działania, a nie powodowały schematycznego "przeklejania” niesprawdzonych wiadomości z mediów elektronicznych.

Z kolei w pytaniu 9 badani zostali poproszeni o określenie: Jak postrzega Pani/ Pan współczesny prestiż zawodu dziennikarza? Większość ankietowanych ocenia ten prestiż jako umiarkowany (14 respondentów - 58,33\%) lub niski (8 respondentów -33,33\%). Udzielone odpowiedzi zostały zaprezentowane na Wykresie 6. 
Wykres 6. Odpowiedzi na pytanie: Jak postrzega Pani/Pan współczesny prestiż zawodu dziennikarza?

\begin{tabular}{|c|c|c|c|c|c|}
\hline jedna odpowiedź & $0 \%$ & $50 \%$ & $100 \%$ & procentowo & głosów \\
\hline Bardzo wysoki & & & & $0 \%$ & 0 \\
\hline Wysoki & $\square$ & & & $4,17 \%$ & 1 \\
\hline Umiarkowany & & & & $58,33 \%$ & 14 \\
\hline Niski & & & & $33,33 \%$ & 8 \\
\hline Bardzo niski & $\square$ & & & $4,17 \%$ & 1 \\
\hline
\end{tabular}

Źródło: opracowanie na podstawie badań własnych.

W pytaniu 10 ankietowani zostali poproszenie o udzielenie odpowiedzi: Jakie widzi Pani/Pan szanse dla siebie jako dziennikarza wynikajace $z$ wpływu nowych mediów na zawód dziennikarza? Respondenci przede wszystkim traktują media elektroniczne jako szeroko rozumiane narzędzie ułatwiające pracę, które nie tylko upraszcza, ale też przyspiesza pozyskanie i weryfikację informacji, pomaga uatrakcyjnić materiał graficznie (np. poprzez filmy lub zdjęcia), wspiera w docieraniu do coraz większej liczby odbiorców. Jeden z respondentów zauważa, że:

Z pewnością [istnieje] większa kontrola społeczna, i to dotycząca zarówno warsztatu, jak i merytoryki. Mówię tu oczywiście o odbiorcach świadomych, interesujących się, zaangażowanych (choć nie w tym sensie, w jakim dziś jest to nadużywane). Taki odbiorca treści jest dziś w stanie bardziej krytycznie spojrzeć na dziennikarski materiał aniżeli jeszcze dwie, trzy dekady temu, kiedy miał ograniczone możliwości np. w sprawdzeniu danej informacji - dziś zajmuje to chwilę. To zmusza (a przynajmniej powinno) do większej rzetelności i sumienności [Dziennikarz 7].

W pytaniu 11 poproszono o udzielenie odpowiedzi: Jakie widzi Pani/Pan zagrożenia dla siebie jako dziennikarza wynikające z wpływu nowych mediów? Najczęściej wymieniano wszechobecność fake newsów, rozpowszechnianych przez nieprofesjonalnych dziennikarzy oraz samych odbiorców. Respondenci zauważyli także zjawisko deep fakeów, które jest jeszcze trudniejsze do wychwycenia. Za zagrożenie uznano też nadmiar informacji, które każdego dnia docierają do odbiorców, oraz funkcjonowanie w konkretnych bańkach informacyjnych. Ponadto niektórzy z badanych stwierdzili, że następuje obniżenie standardów etycznych (np. brak przywołania źródeł informacji, przekazywanie informacji niesprawdzonych) i warsztatowych (np. konieczność rezygnacji z pewnych trudniejszych form dziennikarskich na rzecz form popularnych). Jeden $\mathrm{z}$ respondentów odnotował, że następuje konieczność autopromocji i świadomego budowania marki osobistej, co wymaga innych umiejętności niż dziennikarskie w tradycyjnym rozumieniu ${ }^{28}$.

${ }_{28}$ Zob. A. Modzelewska, Autopromocja i budowanie marki osobistej na portalu Instagram na tle kultury narcyzmu. Analiza zjawiska na podstawie badania dziesięciu najpopularniejszych profili w serwisie, „Zarządzanie Mediami” 2018, nr 1, s. 25-40. 
Pytanie 12 - ostatnie - ma charakter refleksyjny: W jakim kierunku Pani/Pana zdaniem zmierzaja zmiany $w$ zawodzie dziennikarza? Na podstawie odpowiedzi badanych można wskazać sześć kategorii.

1) Postępujący zanik zapotrzebowania na zawód dziennikarza w horyzoncie długoterminowym oraz spadek jakości produktów medialnych:

Skoro coś zanika, to trudno wskazywać na zachodzące zmiany [Dziennikarz 1].

Coraz mniejsza kultura słowa powoduje, że zapotrzebowanie na rzetelną informację podaną przez dziennikarzy z warsztatem zanika [Dziennikarz 19].

Zmierzają w tym kierunku, że ten zawód będzie mógł wykonywać każdy, czyli też osoby nieprzygotowane do tej roli [Dziennikarz 18].

Za chwilę osiągniemy dno dna [Dziennikarz 13].

Coraz większe upodlenie zawodu [Dziennikarz 15].

Raczej wydaje mi się, że zmiany w zawodzie dziennikarza powoli prowadzą w złym kierunku [Współpracownik].

Zmierzają do coraz gorszej jakości dziennikarstwa, do momentu, w którym sami czytelnicy zaczną domagać się jego poprawy [Dziennikarz 3].

Najważniejsze są kliki, najważniejsza jest szybkość podania informacji, w efekcie na dalszy plan schodzi jakość prezentowanego materiału, przedstawienie zdania obu stron sporu itd. [Dziennikarz 9].

Nastawienie na krótkie treści, bycie copywriterem, posiłkowanie się innymi mediami niż własnym researchem [Dziennikarz 10].

Treści coraz mniej wymagające, brak możliwości wprowadzenia w szerszy kontekst. Walka o uwagę czytelnika z wielkimi koncernami. Rotacja w zawodzie [...] [Dziennikarz 12].

Zawód się dewaluuje zarówno pod względem wynagrodzeń, jak i postrzegania przez społeczeństwo, co wynika z tabloidyzacji, upolitycznienia i cięcia budżetów na redakcję/korektę tekstów [Dziennikarz 6].

Chciałabym, żeby podążały w kierunku jeszcze większej specjalizacji dziennikarzy, niestety obecnie wszystkim wydaje się, że mogą być dziennikarzami. To obniża prestiż zawodu, prowadzi również do obniżania wynagrodzeń [Dziennikarz 8].

2) Brak kontroli nad zachodzącymi zmianami:

Przede wszystkim są to zmiany w żaden sposób niekontrolowane. Potrzeba organizacji, która w ramach struktury zrzeszenia dziennikarzy będzie walczyć z fake newsami, ale też edukować pracowników mediów. Zmiany idą w kierunku mediów online, skrótowego podawania informacji [Dziennikarz 20]. 


\section{3) Automatyzacja tworzenia materiałów dziennikarskich:}

W obecnym czasie do przejęcia przez „boty”, tworzenia informacji, artykułów, wszelkich treści przez sztuczną inteligencję. To ogromne zagrożenie, którego możemy już nie zdążyć powstrzymać [Dziennikarz 2].

Wdrażanie technologii sztucznej inteligencji [w redakcjach]. Zapewne proste teksty informacyjne będzie niebawem pisała za dziennikarzy SI [Dziennikarz 12].

\section{4) Niszowość zawodu dziennikarza:}

Dobrzy i profesjonalni dziennikarze przeniosą się do książek, będą też prowadzili niewielkie rubryki do rzadko pojawiających się gazet (większość dzienników drukowanych pewnie przejdzie $w$ tryb wydawania trzy-cztery razy na tydzień). Raz na jakiś czas napiszą większy tekst, ale będą sfrustrowani niską za niego stawką. Reporterzy nie będą wcale pisać do gazet, ponieważ nie będzie się to opłacać; drukować będą tylko teksty, na które pozyskali fundusze z prywatnych źródeł. Dziennikarze newsowi pracować będą wyłącznie nad serwisami i portalami. Zwiększy się udział rynku wideo w portalach informacyjnych. Czytelnicy będą tworzyli na podstawie swoich zainteresowań własną gazetę w aplikacjach. Ostanie się radio jako medium towarzyszące, ale dziennikarze w nim pracujący będą musieli przestawić się na tworzenie profesjonalnych podcastów. Dziennikarstwo telewizyjne będzie się miało gorzej i gorzej, ponieważ stopniowo będą wymierali ludzie, którzy w ogóle oglądają telewizję. Dobre newsroomy redakcyjne przetrwają i będą bardzo profesjonalne, ale będą też świadczyły usługi zewnętrzne, a nie tylko na potrzeby własnej redakcji [Dziennikarz 4].

\section{5) Wielofunkcyjność dziennikarzy:}

1. [Dziennikarz] musi być multimedialny. I napisać, i nagrać, i zrobić zdjęcie. 2. Postępująca specjalizacja. 3. Rosnąć będzie pozycja nowych mediów, niezwiązanych z dotychczasowymi wydawcami [Dziennikarz 5].

Z jednej strony to zmiany pożądane, bo znacznie poszerzają i kompetencje, i umiejętności (np. obsługa, nie tylko techniczna, nowych mediów), ale - niestety to paradoks - z uwagi na specyfikę narzędzi obniżające jednocześnie i poziom merytoryczny użytkowników, i (niekiedy) powagę zawodu [Dziennikarz 7].

Dziennikarstwo już dzieli się na kilka zawodów: od mediaworkera odpowiedzialnego za szybkie, proste newsy po reportażystę, który działa na pograniczu literatury [Dziennikarz 17].

\section{6) Szansa na rozwój:}

W kierunku rozwoju nowych mediów (social media, media internetowe) [Dziennikarz 11].

W ciekawym [kierunku]. Jestem nimi podekscytowana, oby przyniosły samo dobro [Dziennikarz 14].

Do coraz szybszego i wielopoziomowego przekazywania informacji [Dziennikarz 21]. 
Ryszard Filas wskazał sześć hipotez dotyczących przyszłości mediów: stanowisko katastroficzne, totalna elektronizacja tradycyjna, totalna elektronizacja nowoczesna (spersonalizowana), koegzystencja równoprawna, koegzystencja niezrównoważona - odmasowiona, ostra selekcja referencyjna. Przytoczone wypowiedzi respondentów wydają się najbardziej wpisywać w stanowisko katastroficzne wieszczące „śmierć nie tylko prasy (w pierwszym rzędzie dzienników), ale i mediów informacyjnych w ogóle, a w każdym razie informacji wysokiej jakości”29.

\section{Podsumowanie}

Zgromadzony materiał empiryczny umożliwił wysunięcie poniższych wniosków dotyczących współczesnej profesjonalizacji zawodu dziennikarza. Ze względu na zwrot ankiet na poziomie 24 autorzy mają świadomość, że badanie miało charakter pilotażowy, a jego kluczowym walorem jest wskazanie obszarów do dalszej eksploracji.

$\mathrm{Na}$ podstawie przeprowadzonych badań autorzy formułują najważniejsze wnioski:

1. Dziennikarze przystosowali się do zmian wynikających z konwergencji i cyfryzacji, które już nie stanowią dla nich bariery.

2. Zauważalnym problemem środowiska dziennikarskiego jest weryfikacja fake newsów oraz deep fake’ów.

3. Dziennikarze zauważają obniżenie standardów zawodowych i etycznych oraz wskazują na konieczność ich poprawienia.

4. Współczesny profesjonalizm zawodowy dziennikarze rozumieją jako obiektywizm, rzetelność oraz doskonały warsztat.

5. Dziennikarstwo rozumiane jest nie tylko jako profesjonalny przekaz informacji, ale też budowanie długofalowych relacji z odbiorcami.

Społeczeństwo chce wiedzieć, a dziennikarstwo powinno służyć do realizacji tego prawa ${ }^{30}$. Niestety - jak zauważa Marek Chyliński - współcześnie dziennikarstwo przestało stanowić zaporę przed rozpowszechnianiem fałszywych i mylnych informacji ${ }^{31}$. Na problem ten wielokrotnie zwracali uwagę respondenci w badaniu, sugerując konieczność wypracowania mechanizmów służących weryfikacji tego rodzaju informacji.

Przeprowadzone badania potwierdzają zdanie Krzysztofa Mroziewicza, że współczesny dziennikarz opisujący globalną wioskę powinien być sprawnym

${ }^{29}$ R. Filas, Dokad zmierza nasza prasa? Hipotezy i spekulacje, „Zeszyty Prasoznawcze” 2012, nr 1-2, s. 17.

${ }^{30}$ T. Kononiuk, Profesjonalizacja $w$ dziennikarstwie. Między modernizmem a nowoczesnościa, Wydawnictwo Uniwersytetu Warszawskiego, Warszawa 2013, s. 276.

${ }^{31}$ M. Chyliński, Fałszywe wiadomości - antydobra w ekosystemie informacji, „Com.press” 2018, nr 4 (1), s. 20. 
korespondentem, dobrym reporterem, kompetentnym komentatorem $\mathrm{z}$ radiowym głosem i medialną twarzą ${ }^{32}$. Współczesny przemysł medialny wymusza na dziennikarzach wielofunkcyjność i wysokie umiejętności adaptacyjne zwłaszcza w sferze technologicznej. Warto dodać, że zgodnie z wynikami badań Tony’ego Harcupa i Deirdre O’Neill najczęściej publikowane treści powinny spełniać kilka warunków, aby uzyskać akceptację i sympatię odbiorców - przede wszystkim posiadać konstrukcję umożliwiającą ich udostępnianie (shareability) oraz dostarczać rozrywki (entertainment) ${ }^{33}$. Badani dziennikarze podkreślali również, że oczekiwania odbiorców determinują jakość i charakter przygotowywanych materiałów dziennikarskich. Generalnie dominującym poglądem dotyczącym przyszłości profesjonalnego dziennikarstwa jest wizja katastroficzna, wynikająca z oddziaływania nowych mediów, co zaakcentował także Jan Kreft:

Ekspansja programistów i menedżerów zarządzających treściami medialnymi w ramach agregacji staje się zwiastunem końca romantycznej epoki dziennikarstwa tworzonego przez poważanych, „wtajemniczonych” przewodników opisujących i interpretujących rzeczywistość, a nierzadko też ją kształtujących. W nowych mediach coraz mniej jest miejsca dla dziennikarzy, a coraz więcej dla „nie-ludzi”: agregatorów i algorytmów wyszukiwarek dopasowujących treści tworzone przez użytkowników i przez programy komputerowe ${ }^{34}$.

Zdaniem tego autora w procesie agregacji dziennikarze przestają być niezbęd$\mathrm{ni}^{35}$. Odmienny pogląd prezentuje Robert Picard, który uważa, że wobec coraz większych wymagań odbiorców wzrasta zapotrzebowanie na dziennikarzy, ale wyłącznie tych reprezentujących wysoki poziom profesjonalizmu, gdyż samo przekazanie informacji nie jest wystarczające ${ }^{36}$.

\section{Bibliografia}

Adamowski J., Jupowicz-Ginalska A., Zmierzch profesjonalnego dziennikarstwa? Konferencja naukowa Wydziału Dziennikarstwa i Nauk Politycznych Uniwersytetu Warszawskiego i Krajowej Rady Radiofonii i Telewizji, Warszawa, 8 marca 2012, Oficyna Wydawnicza ASPRA-JR, Warszawa 2012.

Chyliński M., Fałszywe wiadomości - antydobra w ekosystemie informacji, „Com.press” 2018, nr 4 (1), s. 6-22.

${ }^{32}$ K. Mroziewicz, Dziennikarz w globalnej wiosce, Wydawnictwa Szkolne i Pedagogiczne, Warszawa 2004, s. 25.

${ }_{33}$ T. Harcup, D. O’Neill, What Is News? News Values Revisited (Again), „Journalism Studies” 2017, nr 18 (12), s. 1470-1488.

${ }^{34}$ J. Kreft, Koniec dziennikarstwa, jakie znamy. Agregacja w mediach, Wydawnictwo Uniwersytetu Jagiellońskiego, Kraków 2016, s. 5.

${ }_{35}$ Tamże, s. 4.

${ }^{36}$ V. Makarenko, G. Piechota, Kto oddzieli ziarno od plew. Wywiad z Robertem Picardem, „Gazeta Wyborcza” 2013, nr 233, s. 20. 
Chyliński M., Metodologia researchu a profesjonalizm dziennikarski, „Studia Medioznawcze” 2012, nr 3 (50), s. 43-61.

Curry J.L., Poland's Journalists: Professionalism and Politics, Cambridge University Press, Cambridge 1990.

Dobek-Ostrowska B., Barczyszyn P., Michel S., Zmiana $w$ dziennikarstwie. Kultura zawodowa polskich dziennikarzy (badania ilościowe), „Studia Medioznawcze” 2013, nr 1, s. 11-26.

Drożdż M., Etyczność jako wyznacznik profesjonalizmu, [w:] K. Wolny-Zmorzyński, K. Konarski (red.), Klinika dziennikarska - credo, Wydawnictwo Uniwersytetu Wrocławskiego, Wrocław 2016, s. 25-42.

Dziennikarski Kodeks Obyczajowy, http://www.dziennikarzerp.pl/wp-content/uploads/2010/06/kodeks.pdf (dostęp: 20.07.2019).

Filas R., Dokąd zmierza nasza prasa? Hipotezy $i$ spekulacje, „Zeszyty Prasoznawcze” 2012, nr 1-2, s. 9-29.

Gałęski B., Zawód jako kategoria socjologiczna. Formowanie się zawodu rolnika, „Studia Socjologiczne" 1963, nr 3 (10), s. 46-72.

Głowacki M., Dziennikarze polscy w świetle studiów porównawczych systemów odpowiedzialności mediów w Europie, „Studia Medioznawcze” 2013, nr 1, s. 29-43.

Hallin D., Mancini P., Systemy medialne. Trzy modele mediów i polityki w ujęciu porównawczym, Wydawnictwo Uniwersytetu Jagiellońskiego, Kraków 2007.

Harcup T., O’Neill D., What Is News? News Values Revisited (Again), „Journalism Studies” 2017, nr 18 (12), s. 1470-1488.

Hofman I., Polityka, media, społeczeństwo. Studia i szkice, Wydawnictwo Adam Marszałek, Toruń 2007.

Jenkins H., Kultura konwergencji. Zderzenie starych i nowych mediów, tłum. M. Bernatowicz, M. Filiciak, Wydawnictwa Akademickie i Profesjonalne, Warszawa 2007.

Karta Etyczna Mediów, http://www.dziennikarzerp.pl/wp-content/uploads/2010/06/karta dziennikarzy.pdf (dostęp: 20.07.2019).

Kodeks Etyki Stowarzyszenia Dziennikarzy Polskich, https://sdp.pl/kodeks-etyki-sdp/ (dostęp: 20.07.2019).

Kononiuk T., Profesjonalizacja $w$ dziennikarstwie. Między modernizmem a nowoczesnościa, Wydawnictwo Uniwersytetu Warszawskiego, Warszawa 2013.

Kononiuk T., Profesjonalizm w prasie lokalnej, „Forum Dziennikarzy” 1999, nr 3, s. 10-11.

Kononiuk T., Zawodowstwo w dziennikarstwie - wyzwania XXI wieku, „Studia Medioznawcze” 2001, nr 3 (4), s. 15-23.

Kreft J., Koniec dziennikarstwa, jakie znamy. Agregacja w mediach, Wydawnictwo Uniwersytetu Jagiellońskiego, Kraków 2016.

Lewandowska M., Profesjonalizm dziennikarski Kuby Wojewódzkiego, Wydawnictwo Naukowe Uniwersytetu Mikołaja Kopernika, Toruń 2019.

Łodyga O., Zawód jako kategoria badań socjologicznych, „Prace Naukowe. Pedagogika” 19992001, nr 8-10, s. 165-171.

Makarenko V., Piechota G., Kto oddzieli ziarno od plew. Wywiad z Robertem Picardem, „Gazeta Wyborcza" 2013, nr 233, s. 20.

Modzelewska A., Autopromocja i budowanie marki osobistej na portalu Instagram na tle kultury narcyzmu. Analiza zjawiska na podstawie badania dziesięciu najpopularniejszych profili w serwisie, „Zarządzanie Mediami” 2018, nr 1, s. 25-40.

Mroziewicz K., Dziennikarz w globalnej wiosce, Wydawnictwa Szkolne i Pedagogiczne, Warszawa 2004. 
Nierenberg B., Media Management: A Comparative Analysis of European and American Systems, Jagiellonian University Press, Kraków 2016.

Olechnicki K., Załęcki P., Słownik socjologiczny, Grafitti, Toruń 1998.

Olędzki J., Polish Journalists: Professionals or Not?, [w:] D.H. Weaver, W. Wu, The Global Journalist: News People around the World, Hampton Press, New York 1998, s. 277-297.

Olędzki J., Profesjonalizm w zawodzie dziennikarskim. Teoria i praktyka, [w:] Polskie przemiany lat 90-tych. Materialy z konferencji naukowej zorganizowanej przez WDiNP UW w dniach 1-2.12.1994 r., Wydawnictwo Uniwersytetu Warszawskiego, Warszawa 1996, s. 267-290.

Olędzki J., Wstęp, [w:] J. Olędzki (red.), Polskie media w okresie przemian, OBP, Warszawa 1991.

Pilch P., Ewolucja denotacji i konotacji pojęcia „profesji”, „Problemy Profesjologii” 2011, nr 2, s. $175-188$.

Pokorna-Ignatowicz K., Problemy zawodowe dziennikarzy w Polsce u progu nowego wieku na podstawie analizy branżowego miesięcznika „Press”, „Studia Medioznawcze” 2001, nr 3 (4), s. 23-34.

Siezieniewska K., Zawód dziennikarza w obliczu konwergencji mediów, Uniwersytet Warszawski, Warszawa 2014.

Słownik języka polskiego, https://sjp.pwn.pl/sjp/profesjonalizm;2572537.html (dostęp: 20.07.2019).

Szot L., Dziennikarze mediów lokalnych. Pomiędzy profesjonalizmem a koniecznościa przetrwania, Wydawnictwo Uniwersytetu Wrocławskiego, Wrocław 2013.

Szot L., Wpływ profesjonalizmu dziennikarzy na transformacje polskiej prasy po 1989 roku, „Studia Medioznawcze” 2010, nr 2 (41), s. 27-38.

Ustawa z dnia 26 stycznia 1984 r. - Prawo prasowe, Dz.U. z 2018 r., poz. 1914.

Ustawa z dnia 29 grudnia 1992 r. o radiofonii i telewizji, Dz.U. z 2019 r., poz. 361 z późn. zm.

Wieczorek P., Dziennikarz profesjonalny czy obywatelski? Przyszłość zawodu w wirtualnym newsroomie, [w:] A. Jaskiernia, K. Gajlewicz-Korab (red.), Rozwój internetu a zmiany $w$ mediach, systemach medialnych oraz społecznych, Wydawnictwo Uniwersytetu Warszawskiego, Warszawa 2016. 
